\title{
Levels of six estrogens in water and sediment from three rivers in Tianjin area, China
}

\author{
Bingli Lei, Shengbiao Huang, Yiqi Zhou, Donghong Wang, Zijian Wang* \\ State Key Laboratory of Environmental Aquatic Chemistry, Research Center for Eco-Environmental Sciences, Chinese Academy of Sciences, Shuangqing Rd. 18, \\ Haidian District, Beijing 100085, PR China
}

\section{A R T I C L E I N F O}

\section{Article history:}

Received 26 September 2008

Received in revised form 11 February 2009

Accepted 12 February 2009

Available online 19 March 2009

\section{Keywords:}

Estrogens

Rivers

Partitioning

Northern China

\begin{abstract}
A B S T R A C T
The occurrence of estrogens in the aquatic environment attracts increasingly attention because of their strong endocrine disrupting potency. In present work, concentrations of six estrogens including diethylstilbestrol (DES), estrone (E1), $\beta$-estradiol (E2), estriol (E3), $17 \alpha$-ethynylestradiol (EE2) and $\beta$-estradiol 17 -valerate (EV) in surface water and sediment sampled from three rivers in Tianjin area, northern China were determined by gas chromatography-mass spectrometry (GC-MS). The concentrations of the total six estrogens ( $\sum 6 \mathrm{ES}$ ) ranged from 0.64 to $174 \mathrm{ng} \mathrm{L}^{-1}$ in waters and from 0.98 to $51.6 \mathrm{ng} \mathrm{g}^{-1}$ dry weight $(\mathrm{dw})$ in sediments, and varied for each river. Among these estrogens, E1 was the most abundant and could be detected in all samples. DES and EV could be detected either in river water or in sediment, but in the concentration range below $10 \mathrm{ng} \mathrm{L}^{-1}$ and $10 \mathrm{ng} \mathrm{g}^{-1}$ for water and sediment, respectively.

The relationships between concentration of estrogens and organic carbon content in sediments and the relationships between sediment-water partition coefficient $\left(\log K_{\mathrm{oc}}\right)$ and octanol-water partition coefficient $\left(\log K_{\text {ow }}\right)$ were examined. The results showed that the contents of the $\sum 6 \mathrm{ES}$ correlated significantly with the contents of organic carbon (OC\%). It indicated that sediments with high organic carbon were more likely to retain estrogens than those with lower organic carbon levels in the natural aquatic environment. Furthermore, the linear correlations between $\log K_{\mathrm{ow}}$ and $\log K_{\mathrm{oc}}$ were obtained for each river, which indicated that sediment-water partitioning of estrogens in three rivers could be predicted by their hydrophobic properties.
\end{abstract}

(C) 2009 Elsevier Ltd. All rights reserved.

\section{Introduction}

Steroidal estrogens are one class of moderately hydrophobic compounds and exist widely in the aquatic environment. These substances are extremely potent compounds. Their estrogenic effects on fish have been observed in laboratory studies down to $0.2-1 \mathrm{ng} \mathrm{L}^{-1}$ which were lower than those commonly detected in the aquatic environment (Legler et al., 2002; Campbell et al., 2006; Labadie and Budzinski, 2006; Zha et al., 2008). Steroidal estrogens are excreted mainly in the urine of human and mammalians, and a small proportion in the feces (Hanselman et al., 2003). Some livestock wastewater and domestic sewage containing estrogens are directly discharged into the receiving rivers or via the effluent of sewage treatment plants (STPs) or through runoff of sewage sludge used in agriculture, enter waterways (Hanselman et al., 2003; Samir et al., 2006; Björkblom et al., 2008).

In the past decades, some papers have been devoted to the occurrences of steroidal estrogens in natural waters. Tabata et al. (2001) conducted an extensive survey of estrogenic steroids in 109 Japanese rivers and found E2 with a mean concentration of $2.1 \mathrm{ng} \mathrm{L}^{-1}$. E1, E2, E3 and EE2 were found in Tiber river water in

\footnotetext{
* Corresponding author. Tel./fax: +86 1062849140.

E-mail address: wangzj@rcees.ac.cn (Z. Wang).
}

Italy with a concentration of $1.5,0.11,0.33$ and $0.04 \mathrm{ng} \mathrm{L}^{-1}$, respectively (Baronti et al., 2000). In seven French rivers, estrogens were detected in the range from $0.8-3.9 \mathrm{ng} \mathrm{L}^{-1}$ for $\mathrm{E} 1,0.8-3.6 \mathrm{ng} \mathrm{L}^{-1}$ for E2, 0.6-3.1 ng L ${ }^{-1}$ for E3 and 0.6-3.5 ng L $^{-1}$ for EE2 (Cargouët et al., 2004). However, there were high levels of estrogens in polluted rivers. For example, Kolpin et al. (2002) surveyed 139 polluted streams and rivers in the US and found the maximum concentrations of $112 \mathrm{ng} \mathrm{L}^{-1}$ for E1, $200 \mathrm{ng} \mathrm{L}^{-1}$ for E2 and $51 \mathrm{ng} \mathrm{L}^{-1}$ for E3. The largest concentration of E1 is up to $30 \mathrm{ng} \mathrm{L}^{-1}$ in the Jalle d'Eysines River of France (Labadie and Budzinski, 2005). In most reports, there were low levels of estrogens in surface sediments, ranging from ND-10 $\mathrm{ng} \mathrm{g}^{-1}$ (Ternes et al., 2002; Liu et al., 2004; Braga et al., 2005; Isobe et al., 2006; Viganò et al., 2008). However, Lopez de Alda et al. (2002) reported a maximum concentration of $22.8 \mathrm{ng} \mathrm{g}^{-1}$ for EE2 and $11.9 \mathrm{ng} \mathrm{g}^{-1}$ for E1 from two rivers in the North-East of Spain. In wastewater treatment plant influents and effluents, steroidal estrogens have been surveyed extensively in different countries and their concentrations generally ranged from 10 to $200 \mathrm{ng} \mathrm{L}^{-1}$ (Ternes et al., 1999a; Baronti et al., 2000; Andersen et al., 2003; Labadie and Budzinski, 2005; Esperanza et al., 2007; Zhang and Zhou, 2008). However, little information is available on their concentration levels in Chinese rivers and there were little data on the occurrences of EV and DES in the aquatic environment. 
The environmental behavior of estrogens has been also reported, but mostly through laboratory-based simulation experiment. Like other hydrophobic organic chemicals, the partitioning of estrogens between water and solid were found to be influenced by the organic content of the solid (Lai et al., 2000; Holthaus et al., $2002)$. The sediment-water partition coefficient $\left(\log K_{\mathrm{oc}}\right)$ and octanol-water partition coefficient $\left(\log K_{\text {ow }}\right)$ values of estrogens (E1, E2, E3 and EE2) ranged from about 3.25-3.70 and 2.81-4.15, respectively (Ying et al., 2002). DES and EV have higher $\log K_{\text {ow }}$ values of 5.07 and 6.41, respectively (Lai et al., 2000; Kuster et al., 2004). These data indicate that estrogenic steroids are hydrophobic organic compounds and adsorb easily onto organic carbon rich sediments (Ying et al., 2002). The hypothesis that estrogens (E1, E2 and EE2) would partition easily to organic carbon rich sediments has been supported by modeling data and laboratory experiments using E2 (Lai et al., 2000). However, there was no evidence that the behavior of estrogens in the natural aquatic environment were affected by natural organic carbon.

This study focused on distribution characterization of six estrogens in surface water and sediment in Tianjin area, northern China. The data could be useful to further evaluate the potential ecological risk of these estrogens in these rivers.

\section{Materials and methods}

\subsection{Study areas and sampling locations}

Samples were taken from the Beitang River, Dagu River and Yongding New River in Tianjin area, northern China. Tianjin has a long history as an industrial city with a total population of 9.39 millions. Agricultural population is 3.77 millions and non-agricultural population is 5.62 millions (Tianjin Municipality Government, 2005). The Beitang and Dagu River flow through a chemical industry zone. Furthermore, there are compact villages, small towns and farmlands along the rivers. Industrial, agricultural and domestic wastewaters from Tianjin area are directly or indirectly discharged into the Beitang, Dagu and Yongding New River which carry the water to the Bohai Sea (Song et al., 2006). The Beitang and Dagu River are two drainage rivers which receive and transport most of domestic, industrial and agricultural wastewaters from Tianjin area (Liu et al., 2007). The Yongding New River is natural water with an area of $83000 \mathrm{~km}^{2}$ and is an important flood river in the Haihe River basin. The Yongding New River receives also discharged contaminants in recent years because of rapid economic development (Tianjin Environmental Protection Bureau, 2001).

The sampling sites were set along the rivers according to the location of chemicals factories (b6, b7, d3, d14, d15), drainage outlets or sewage brakes (b1-b5, d1, d2, d8-d12, d17, y2, y10), bridges (d4, d5, d7, d16, y1, y4, y7), high roads (y3, y9), river confluence reaches (b8, d6, d13, y6, y11), tributaries of rivers (y5, y8) and entrances of rivers (d18, y12) (Fig. 1). Throughout the survey a global positioning system (GPS) was used to locate the sampling locations. The 38 sediment samples (a mixture of sediment from the upper $20 \mathrm{~cm}$ ) were collected by a grab sampler (Wildlife Supply Company, SAGINAW, Michigan, USA) in June 2007. Sediment samples were homogenized on site and stored in clean stainless-steel containers. All samples were immediately sealed and stored at $4{ }^{\circ} \mathrm{C}$ until analysis. Surface water samples were collected at the same time and at the same sites with the sediment samples. Water samples were taken using pre-cleaned glass bottles with Teflonlined cap, and then formaldehyde $(1 \%, \mathrm{v} / \mathrm{v})$ was added immediately to prevent bacterial degradation of natural steroids (Labadie and Budzinski, 2005). Filtration was carried out within $12 \mathrm{~h}$ after sample collection.

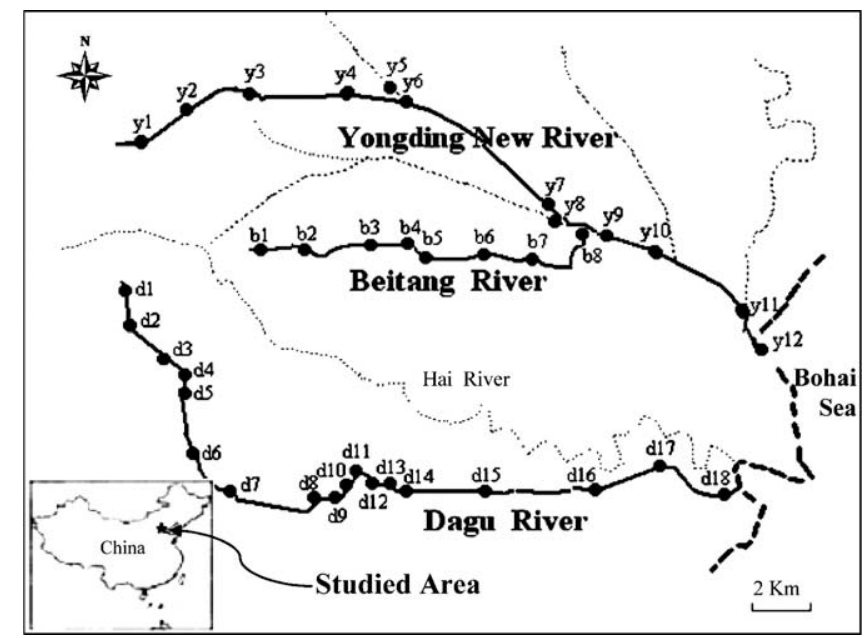

Fig. 1. Sampling sites.

\subsection{Chemicals and materials}

Target compounds are steroidal estrogens including three natural estrogens of estrone (E1), $\beta$-estradiol (E2) and estriol (E3), and three synthetic estrogens of $17 \alpha$-ethynylestradiol (EE2), diethylstilbestrol (DES) and $\beta$-estradiol-17-valerate (EV). All target compounds are of the highest purity commercially available. E1, E2, EE2 and EV were purchased from Sigma-Aldrich, USA. E3 and DES were purchased from Flucka, The Netherlands. Derivatization reagents of bis(trimethyl)-trifluoroacetamide (BSTFA) containing $1 \%$ of trimethylchlorosilane (TCMS) and trimethylsilylimidazole (TMSI) were purchased from Supelco, USA and Sigma-Aldrich, Germany, respectively. Internal standard pyrene- $\mathrm{d}_{10}$ was purchased from Supelco, USA. Acetone, N-hexane, dichloromethane (DCM), methanol $(\mathrm{MeOH})$, ethyl acetate, and cyclohexane were HPLC grade and were purchased from Mallinckrodt, USA. Sodium sulfate (analytical reagent grade, Mallinckrodt USA) was sequentially rinsed with acetone, DCM and hexane for three times each, and completely dried in the fume hood. The dried sodium sulfate was baked at $450{ }^{\circ} \mathrm{C}$ for $4 \mathrm{~h}$ and stored in desiccator. The silica gel (60-200 mesh, Acros Organics USA) and neutral alumina (50-200 mesh, Acros Organics USA) were activated at $180^{\circ} \mathrm{C}$ and $250{ }^{\circ} \mathrm{C}$ for $12 \mathrm{~h}$, respectively, and then stored in desiccator. All glassware were treated with sulphochromic mixtures at first, and washed successively with deionized water, HPLC grade acetone and hexane before use.

A stock solution of all target chemicals in a concentration of $10 \mathrm{mg} \mathrm{mL}^{-1}$ was prepared in methanol and stored in an amber glass vial at $-20^{\circ} \mathrm{C}$. The working solutions of the individual standards and their mixtures were prepared by serial dilution of stock solutions with pure $\mathrm{N}$-hexane and stored at $4{ }^{\circ} \mathrm{C}$.

\subsection{Analytical procedures}

\subsubsection{Pretreatment of water samples}

The method of pretreatment for water samples was based on previous reports (Jeannot et al., 2002; Trenholm et al., 2006). The two liters water samples were filtered using $0.45 \mu \mathrm{m}$ PTFE fiberglass filters (Millipore, Bedford, MA, USA) to remove suspended particulate matter (SPM), and adjusted $\mathrm{pH}$ to 2-3 with hydrochloric acid. Extraction of the analytes was performed using $500 \mathrm{mg}$ Oasis HLB (Hydrophilic-Lipophilic Balanced copolymer) cartridge (flow rate $5-10 \mathrm{~mL} \mathrm{~min}^{-1}$ ). The HLB cartridge was conditioned with $6 \mathrm{~mL}$ of tert-butyl methyl ether, $5 \mathrm{~mL}$ of methanol and $5 \mathrm{~mL}$ of Milli-Q water prior to use. The cartridge was then rinsed 
sequentially with $5 \mathrm{~mL}$ of methanol/Milli-Q water $(1: 3, \mathrm{v} / \mathrm{v}), 5 \mathrm{~mL}$ of Milli-Q water and $5 \mathrm{~mL}$ of methanol/ammonia/ultra-pure water $(10: 2: 88, v / v / v)$. After drying by vacuum pressure, the analytes were eluted with $10 \mathrm{~mL}$ of methanol/tert-butyl methyl ether (1/ $9, \mathrm{v} / \mathrm{v}$ ). The eluate was evaporated to just dryness under a gentle stream of high purity nitrogen gas.

\subsubsection{Pretreatment of sediment samples}

A freeze-dried sediment $(10 \mathrm{~g})$ was put into a $50 \mathrm{~mL}$ amber glass vial with PTFE screw cap and sonicated with $15 \mathrm{~mL}$ of acetone/methanol $(1: 1, \mathrm{v} / \mathrm{v})$ in an ultrasonic bath (Institute of acoustics, CAS, China) for $20 \mathrm{~min}$. The slurry was then centrifuged at $825 \mathrm{~g}$ for $5 \mathrm{~min}$, and the supernatants were collected. The sonication was performed three times and the extract was combined. The extract was then reduced to about $0.5 \mathrm{~mL}$ by rotary evaporator (Büchi Rotavpor R-200, Switzerland) and a gentle flow of high purity nitrogen gas.

The concentrated sediment extract was dissolved in $10 \mathrm{~mL}$ of ethyl acetate/cyclohexane $(1: 1, \mathrm{v} / \mathrm{v})$ and $5 \mathrm{~mL}$ was injected into the GPC column (CO785, Accuprep MPSTM, J2 Scientific USA) to remove matrix components with high molecular masses ( $z 1000 \mathrm{amu}$ ) (Ternes et al., 2002). A mixture of ethyl acetate/ cyclohexane $(1: 1, v / v)$ was used as eluent, and the flow rate was adjusted to $4.7 \mathrm{~mL} \mathrm{~min}^{-1}$. The first fraction, from 0 to $8 \mathrm{~min}$, which contained higher-molecular-weight compounds, was discarded. The second fraction containing the estrogens was collected between 8 and $20 \mathrm{~min}$. The eluate of the second fraction was reduced to about $0.5 \mathrm{~mL}$.

The following purification was performed by silica gel and neutral alumina chromatographic column. The activated silica gel and neutral alumina were partially deactivated with $3 \%$ water $(\mathrm{w} / \mathrm{w})$ and immersed in hexane. A chromatographic column with a Teflon stopcock $(200 \mathrm{~mm} \times 10.5 \mathrm{~mm}$ I.D. $)$ was plugged with glass wool at the bottom and then filled column half full with hexane. The column was wet-packed successively with $4 \mathrm{~cm}$ deactivated silica gel, $4 \mathrm{~cm}$ deactivated neutral alumina and $2 \mathrm{~cm}$ anhydrous sodium sulfate. The column was tapped to settle the silica gel and alumina. The concentrated sediment extract after GPC cleanup was transferred cautiously to the prepared compound column of silica gel and alumina using pipette. The analytes were eluted successively using $10 \mathrm{~mL}$ of hexane, $20 \mathrm{~mL}$ of hexane/acetone $(65: 35, v / v)$ and $40 \mathrm{~mL}$ of acetone/methanol $(1: 1, \mathrm{v} / \mathrm{v})$. Six steroidal estrogens were in the acetone/methanol fraction. The acetone/ methanol eluate was collected and then evaporated to just dryness.

\subsubsection{Derivatization and instrumental analysis}

The derivatization and analytical conditions of target compounds were based on the method from Zhou et al. (2007). The residues of water and sediment samples were redissolved in $0.4 \mathrm{~mL}$ of hexane that contained $50 \mu \mathrm{L}$ of the derivatization mixture BSTFA/ TCMS/TMSI $(99: 1: 0.5, \mathrm{v} / \mathrm{v} / \mathrm{v})$ and $50 \mathrm{ng} \mathrm{mL}^{-1}$ of pyrene- $\mathrm{d}_{10}$. The derivatization was performed at $60{ }^{\circ} \mathrm{C}$ for $30 \mathrm{~min}$. The derivatives were cooled at room temperature and stored at $4{ }^{\circ} \mathrm{C}$. The instrumental analysis was performed within two days.

The separation and detection of the target compounds were achieved by GC-MS (Agilent 6890 with mass spectrometer Agilent 5973 MSD, Agilent Technologies, USA). System control and data acquisition were achieved with ChemStation Software. One micro-liter of derivatives was injected into DB-5 MS column (30 $\mathrm{m} \times 0.25 \mathrm{~mm} \times 0.25 \mu \mathrm{m}$ film thickness) in splitless mode. Helium (99.9999\%) was used as carrier gas and the flow rate was set

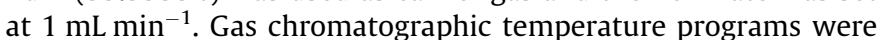
as follows: initial temperature was $80^{\circ} \mathrm{C}$ held $1 \mathrm{~min}$, increased to $200{ }^{\circ} \mathrm{C}$ at a rate of $20^{\circ} \mathrm{C} \mathrm{min}^{-1}$, then increased to $300{ }^{\circ} \mathrm{C}$ at a rate of $10^{\circ} \mathrm{C} \mathrm{m^{-1 }}$ and held $10 \mathrm{~min}$, with a total run of $27 \mathrm{~min}$ and sol- vent delay $6 \mathrm{~min}$. The injector and detector temperatures were set at $280^{\circ} \mathrm{C}$. The ion source temperature was $230^{\circ} \mathrm{C}$, and the energy of the ionizing electron was $70 \mathrm{eV}$.

\subsection{Quality assurance and quality control}

All data were subject to strict quality control procedures. Before analysis, relevant standards were run to check column performance, peak height, resolution and sensitivity. With each set of samples analyzed, a solvent blank, a procedural blank and a standard mixture of six estrogens were run in sequence to check contamination, peak identification and quantification. None of the target compounds were detected in the procedural blanks for water and sediment. Qualitative analysis of target compounds was accomplished at the basis of retention time and mass spectrum together in a full scan model. Characteristic ions/quantification ions for each substance are 212, 106/212 for pyrene-d16, $412,397,383 / 412$ for DES, 342, 218, 257/342 for E1, 416, 285, $129 / 416$ for E2, 425, 285, 440 for 425 for EE2, 504, 129, 345/504 for E3, and 428, 231, 244/428 for EV, respectively. Quantitative analysis was performed in a selected ion monitoring (SIM) mode using internal standard calibration. Initially, a series of injections of target compounds in the concentration range from 0.5 to $500 \mathrm{ng} \mathrm{mL}^{-1}$ with constant internal standard $\left(50 \mathrm{ng} \mathrm{mL}^{-1}\right)$ were performed to determine the linear concentration range. Good linearity was observed with correlation coefficients above 0.99. Calibration curves were obtained by linear regression analysis to calculate unknown concentration.

The limit of detection (LOD) and limit of quantification (LOQ) for this method were achieved by concentrating $2 \mathrm{~L}$ waters and extracting $10 \mathrm{~g}$ sediments. They were calculated as the minimum amount of a compound present in the sample that produced a signal to noise ratio of three to six, based on an injection of $1 \mu \mathrm{L}$ aliquot of the final $0.4 \mathrm{~mL}$ extraction solution (Zhou et al., 2009). The limit of detection (LOD) and limit of quantification (LOQ) for water were $0.10-0.65 \mathrm{ng} \mathrm{L}^{-1}$ and $0.2-1.3 \mathrm{ng} \mathrm{L}^{-1}$, respectively. For sediment, they were $0.06-0.1 \mathrm{ng} \mathrm{g}^{-1}$ and $0.12-0.2 \mathrm{ng} \mathrm{g}^{-1}$, respectively. The recovery study was performed on samples spiked with known levels ( $100 \mathrm{ng} \mathrm{L}^{-1}$ ) of the estrogens. Four replicates for each sample were carried out at levels of $10 \mathrm{ng} \mathrm{L}^{-1}$ for water and $10 \mathrm{ng} \mathrm{g}^{-1}$ for sediment. Mean recoveries were higher than $79 \%$ for most compounds, except for E3, which showed lower recovery at $72 \%$ and $66 \%$ for water and sediment samples, respectively. Relative standard deviations (RSD) were $5-15 \%$ for water and $8-16 \%$ for sediment.

\subsection{Determination for organic carbon contents of sediment samples}

About $20 \mathrm{~g}$ of wet sediment samples was dried to constant weight at $105{ }^{\circ} \mathrm{C}$. The dried sediment was heated at $550{ }^{\circ} \mathrm{C}$ for $1 \mathrm{~h}$ in order to determine the organic matter (Xue et al., 2006). The organic matter was denoted by loss on ignition (LOI\%) and organic carbon contents (OC\%) were estimated as equation $(\mathrm{OC} \%=0.458 \times$ LOI\% -0.4$)$ described by Xue et al. (2006).

The organic carbon contents of sediments ranged from $0.51-$ $13.9 \%$ (mean $5.30 \%$ ) for the Beitang River, 0.84-10.1\% (mean $3.92 \%$ ) for the Dagu River, and $0.64-2.67 \%$ (mean $1.24 \%$ ) for the Yongding New River. The organic carbon contents of sediment samples from the Beitang River and Dagu River are higher than ones from the Yongding New River. A possible reason is that there are low flow rate of river water and large amount of wastewater discharges resulting in higher organic carbon contents in the drainage rivers than ones in the natural river. Three replicates were performed to determine the variation of organic carbon contents (OC\%) measured for each sediment sample with the standard deviation range from $0.13 \%$ to $1.5 \%$. 


\section{Results and discussion}

\subsection{Levels and spatial distribution of six estrogens in water and sediment from three rivers}

Despite the restriction on the usage of some estrogens, the analyzed samples showed that the presence of six estrogens in water and sediment were at concentrations above the method of detection limits. The results of six estrogens concentrations in water and sediment are shown in Table 1. The concentration levels of the total six estrogens ( $\sum 6 \mathrm{ES}$ ) in water were $8.55-110 \mathrm{ng} \mathrm{L}^{-1}$ for the Beitang River (mean $54.9 \mathrm{ng} \mathrm{L}^{-1}$ ), 12.9-174 $\mathrm{ng} \mathrm{L}^{-1}$ for the Dagu River (mean 55.3 $\mathrm{ng} \mathrm{L}^{-1}$ ) and 0.64-66.2 $\mathrm{ng} \mathrm{L}^{-1}$ for the Yongding New River (mean $25.6 \mathrm{ng} \mathrm{L}^{-1}$ ). For sediment samples, they were 2.67-50.7 $\mathrm{ng} \mathrm{g}^{-1}$ (mean 28.5 $\mathrm{ng} \mathrm{g}^{-1}$ ), 8.2-51.6 $\mathrm{ng} \mathrm{g}^{-1}$ (mean $22.5 \mathrm{ng} \mathrm{g}^{-1}$ ) and $0.98-29.6 \mathrm{ng} \mathrm{g}^{-1}$ (mean $13.4 \mathrm{ng} \mathrm{g}^{-1}$ ), respectively. In comparison, the similar mean concentrations of six estrogens were found in the Beitang and Dagu River, which were higher than those in the Yongding New River. It indicated that the drainage river received more estrogens discharges than the natural river. Among all sampling sites, high concentrations of the total six estrogens ( $\sum 6 \mathrm{ES}$ ) were found in water samples at sites b1, b6, d1, d8 and d10 above $70 \mathrm{ng} \mathrm{L}^{-1}$ and in sediment samples at sites b1, b2, $\mathrm{d} 1$ and $\mathrm{d} 10$ above $40 \mathrm{ng} \mathrm{g}^{-1}$. The most contaminated sample was $\mathrm{d} 10$ and the $\sum 6 \mathrm{ES}$ concentrations were $174 \mathrm{ng} \mathrm{L}^{-1}$ and $51.6 \mathrm{ng} \mathrm{g}^{-1}$ for water and sediment matrix, respectively. According to the investigations for sampling sites, these sites are generally situated in the drainage outlets or sewage brakes which mainly discharge domestic wastewater. Therefore, it was possible to find high levels of estrogens at these sampling sites. Low concentrations of the total six estrogens were found in water samples at sites b3, y4, y5, y6, y7 and y12 below $10 \mathrm{ng} \mathrm{L}^{-1}$ and in sediment samples at sites b4, $\mathrm{d} 13, \mathrm{y} 4, \mathrm{y} 5, \mathrm{y} 7, \mathrm{y} 11$ and y12 below $10 \mathrm{ng} \mathrm{g}^{-1}$. These sampling sites are generally situated in tributaries or confluences of the rivers. A possible reason is that the confluence of other river provokes a dilution and results in lower levels of estrogens at these sampling sites.

E1 was detected at all sampling sites and its concentrations were higher than those of E2. It had been reported that concentrations of E1 were higher than those of E2 in sewage effluents and in river water because of oxidation of E2 to E1 (Andersen et al., 2003; Williams et al., 2003). Ternes et al. (1999b) also reported that 95\% of E2 transformed into E1 in 1-3 h in sludge. If this transformation process also occurs in the natural aquatic environment, more widespread distribution of E1 compared with E2 is expected. At the same time, the higher concentrations of E3 than those of E2 and EE2 were also found in the river water. This agrees with previous reports that the concentrations of E1 and E3 were generally higher than those of E2 and EE2 in water (Baronti et al., 2000). A possible explanation is that E2 and EE2 can transform easier into E1 then degrade into E3 in the aquatic environment (Arcand-Hoy et al., 1998). Adlercreutz et al. (1994) also reported that daily urine excretions of E1, E2, and E3 in oriental premenopausal women were $2.66,1.09$, and $5.68 \mu \mathrm{g}$. These would explain the higher levels of E1 and E3 in river water. Whereas in sediment samples, the concentrations of E3 were found lower than those of E1, E2, EE2 and $\mathrm{EV}$. A possible reason is that $\log K_{\mathrm{ow}}$ value (2.81) of E3 is lower than ones (3.43-6.41) of other target estrogens (Johnson, 1999). It had been reported that the biotransformation rate of estrogens increases until $\log K_{\text {ow }}$ reaches 3-3.5, after which sorption processes dominates their fate in treatment processes and the environment (Gomes et al., 2004). Therefore, E1, E2, EE2, and EV with the $\log K_{\text {ow }}$ of 3.43-6.41 would be expected to demonstrate a preference to partitioning in the solid phase.

The concentration of DES was lower than other five estrogens both in water or sediment samples from three rivers. DES was once taken during gestation to prevent spontaneous abortions in women from 1948 to 1971. It was known to produce adverse effects and was banned in recent years (Yang et al., 2006). This was consistent with lower DES concentrations detected in samples in this study.

There were some reports on the levels of estrogens including E1, E2, E3 and EE2 in surface waters (Table 2) and sediments (Table 3 ) from other locations. Their concentrations generally ranged from ND to $20 \mathrm{ng} \mathrm{L}^{-1}$ for water and ND to $10 \mathrm{ng} \mathrm{g}^{-1}$ for sediment. In the majority of the studies, E3 levels were very low or below the detection limit and E1 was the most frequently detected estrogen.

The levels of steroidal estrogens from the two drainage rivers were higher in comparison with those from Japan and European countries where they received the treated wastewater. However for the two drainage rivers, they received not only treated wastewater, but also untreated domestic sewage and livestock-breeding wastewater from the catchment with higher population density (Tianjin Environmental Protection Bureau, 2001). An USGS (US Geological Survey) study revealed that higher levels of estrogenic steroids in streams relative to most reports probably because their targeted sites were susceptible to contamination from human, industrial, and agricultural wastewater (Kolpin et al., 2002). Kolodziej et al. (2004) also demonstrated that sources other than municipal wastewater (such as farming wastes) could contribute to the level of steroid hormones in surface waters.

\subsection{The correlation between estrogens ( $\left.\sum 6 E S\right)$ and organic carbon (OC\%) in sediments}

In this study, six estrogens were taken as a type of compounds and the sum of the concentrations of the six estrogenic compounds were used for correlation with the organic carbon instead of plotting the individual estrogens because they all belong to steroid compounds and have similar sorption properties (Clara et al., 2004). As shown in Fig. 2, positive correlation between $\sum 6 \mathrm{ES}$ and the contents of organic carbon (OC\%) could be found and the correlation coefficients $\left(R^{2}\right)$ were 0.73 for the Beitang River, 0.56

Table 1

The concentration range and mean of six estrogens in water (ng $\left.\mathrm{L}^{-1}\right)$ and sediment samples (ng $\mathrm{g}^{-1}$, dw) from three rivers in Tianjin area.

\begin{tabular}{|c|c|c|c|c|c|c|}
\hline \multirow[t]{2}{*}{ Estrogens } & \multicolumn{2}{|l|}{ Beitang River } & \multicolumn{2}{|l|}{ Dagu River } & \multicolumn{2}{|c|}{ Yongding New River } \\
\hline & Water & Sediment & Water & Sediment & Water & Sediment \\
\hline DES & ND-3.91 (2.13) & ND-4.51 (2.61) & ND-3.47 (1.31) & ND-4.41 (1.69) & ND-8.51 (1.88) & ND-4.23 (1.53) \\
\hline E1 & $4.29-49.8(23.4)$ & $1.03-21.4(9.89)$ & $5.00-55.3(19.7)$ & $2.15-21.6(7.54)$ & $0.64-20.2(10.5)$ & $0.98-8.13(4.62)$ \\
\hline E2 & $2.51-21.2(8.69)$ & $0.71-9.70(5.28)$ & $0.93-32.4(10.3)$ & $1.60-9.23(4.40)$ & ND-13.6 (7.26) & ND-5.63 (3.34) \\
\hline EE2 & $1.64-24.4(10.0)$ & $0.93-7.67$ (5.09) & ND-35.6 (9.45) & $0.81-9.26(4.02)$ & ND-12.0 (3.54) & ND-5.77 (2.75) \\
\hline E3 & ND-15.4 (10.3) & ND-6.99 (3.08) & $2.26-46.4(12.4)$ & ND-7.29 (2.61) & ND-10.8 (5.76) & ND-3.77 (1.97) \\
\hline EV & ND-7.66 (3.57) & ND-6.44 (3.77) & ND-8.47 (3.53) & ND-9.45 (3.61) & ND-2.30 (1.29) & ND-4.13 (2.31) \\
\hline$\sum 6 \mathrm{ES}$ & $8.55-110(54.9)$ & $2.67-50.7(28.5)$ & $12.9-174(55.3)$ & $8.20-51.6(22.5)$ & $0.64-66.2(25.6)$ & $0.98-29.6(13.4)$ \\
\hline
\end{tabular}

ND $=$ not detected. 
Table 2

Comparison of estrogens concentrations $\left(\mathrm{ng} \mathrm{L}^{-1}\right)$ in the water in rivers, oceans and estuaries from other locations.

\begin{tabular}{|c|c|c|c|c|c|}
\hline Locations & E1 & E2 & E3 & EE2 & References \\
\hline Paris seven Rivers, France & $0.8-3.9$ & $0.8-3.6$ & $0.6-3.1$ & $0.6-3.5$ & Cargouët et al. (2004) \\
\hline Jalle d'Eysines River, France & ND-30 & ND-1.5 & ND-1.8 & ND-2 & Labadie and Budzinski (2005) \\
\hline Dutch surface water, The Netherlands & $0.3-7.2$ & $0.8-1.0$ & - & $0.3-0.4$ & Vethaak et al. (2005) \\
\hline Coastal/estuarine and rivers, The Netherlands & $0.1-3.4$ & $0.3-5.5$ & - & $0.1-4.3$ & Belfroid et al. (1999) \\
\hline Scheldt estuary, Belgium & $0.37-10$ & ND & - & ND & Noppe et al. (2007) \\
\hline Tama River, Japan & 8.7-19.7 & $4.2-5.3$ & - & ND & Kawaguchi et al. (2004) \\
\hline Lake Kasumigaura, Japan & $0.2-0.8$ & ND & - & ND & Isobe et al. (2003) \\
\hline Rhine, Ahr and Agger River, Germany & $1.3-9.2$ & - & - & $0.3-1.0$ & Hintemann et al. (2006) \\
\hline Rivers and creeks, Germany & $0.10-4.1$ & $0.15-3.6$ & - & $0.10-5.1$ & Kuch and Ballschmiter (2001) \\
\hline Tiber River, Italy & 1.5 & 0.11 & 0.33 & 0.04 & Baronti et al. (2000) \\
\hline Lake TaiHu, China & - & $5.5-15.5$ & ND & $5.7-30.8$ & Shen et al. (2001) \\
\hline Dan-Shui River, China (Taiwan) & $22.4-66.2$ & $1.4-33.9$ & $12.4-73.6$ & $7.53-27.4$ & Chen et al. (2007) \\
\hline Beitang River, China & $4.29-49.8$ & $2.51-21.2$ & ND-15.4 & $1.64-24.4$ & This study \\
\hline Dagu River, China & $5.00-55.3$ & $0.93-33.4$ & $2.26-46.4$ & ND-35.6 & \\
\hline Yongding New River, China & $0.64-20.2$ & ND-13.6 & ND-10.8 & ND-12.0 & \\
\hline
\end{tabular}

$\mathrm{ND}=$ not detected.

Table 3

Comparison of estrogens concentrations $\left(\mathrm{ng} \mathrm{g}^{-1} \mathrm{dw}\right)$ in the sediments in rivers, oceans and estuaries from other locations.

\begin{tabular}{|c|c|c|c|c|c|}
\hline Locations & E1 & E2 & E3 & EE2 & References \\
\hline Ouse and Uck River, England & ND-3 & ND-4 & - & ND-9 & Liu et al. (2004) \\
\hline Tokyo Bay, Japan & $0.05-3.6$ & ND-0.59 & ND & ND & Isobe et al. (2006) \\
\hline Rivers, Germany & $0.2-2$ & ND-1.5 & - & ND-0.9 & Ternes et al. (2002) \\
\hline Malabar ocean, Australia & $0.16-1.17$ & $0.22-2.48$ & - & ND-0.5 & Braga et al. (2005) \\
\hline Anoia and Cardener River, Spain & ND-11.9 & ND & ND-3.37 & ND-22.8 & Lopez de Alda et al. (2002) \\
\hline Beitang River, China & $1.03-21.4$ & $0.71-9.70$ & ND-6.99 & $0.93-7.67$ & This study \\
\hline Dagu River, China & $2.15-21.6$ & $1.60-9.23$ & ND-7.29 & $0.81-9.26$ & \\
\hline Yongding New River, China & $0.98-8.13$ & ND-5.63 & ND-3.77 & ND-5.77 & \\
\hline
\end{tabular}

$\mathrm{ND}=$ not detected.
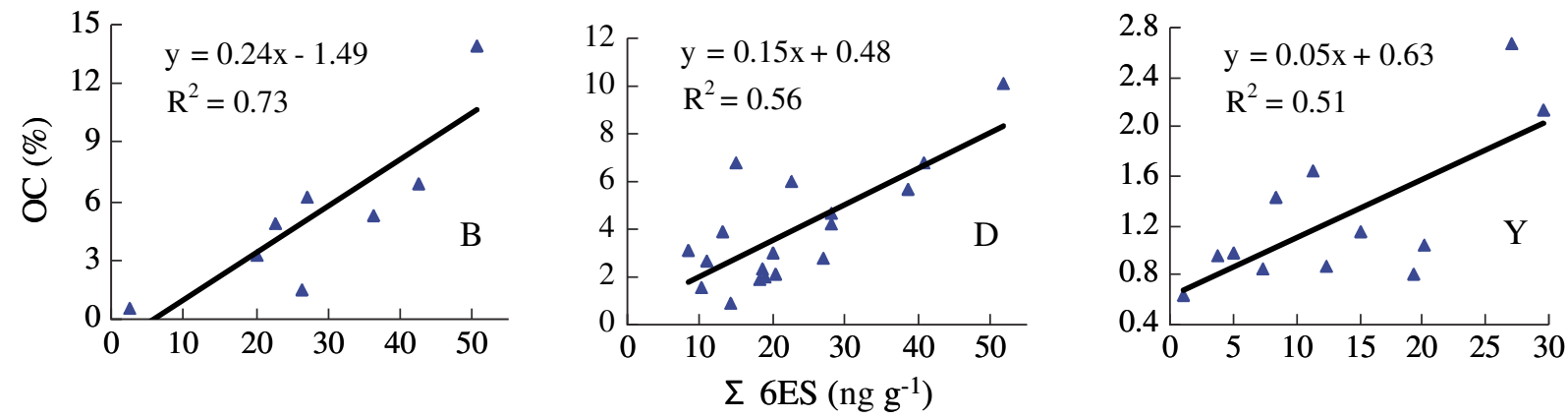

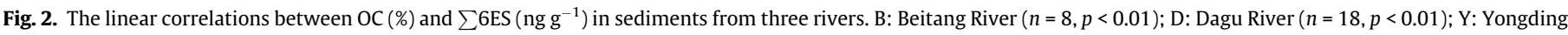
New River $(n=12, p<0.01)$.

for the Dagu River and 0.51 for the Yongding New River, respectively. It indicated that sediments with high organic carbon were more likely to absorb estrogens than those with lower organic carbon levels. This is in agreement with the results that the higher amounts of estrogens could occur in sediments with high organic matter content (Gobas and Maclean, 2003; Samir et al., 2006). Meanwhile, Lai et al. (2000) also reported that although the presence of organic carbon was not a prerequisite for sorption, the sorption of estrogens to sediments seems to correlate to OC (\%).

\subsection{In situ sediment-water partition coefficient}

The degree of sediment-water partitioning of a substance plays a key role in the food-chain transfer of the substance, in modeling the environmental fate and in the development of sediment quality criteria (Gobas and Maclean, 2003). To understand the equilibrium partitioning and kinetic geochemistry of compounds in the environment, several partition models have been developed by laboratory experiment or model simulation (Sabljic et al., 1995; Casey et al., 2003; Gobas and Maclean, 2003; Yamamoto et al., 2003; Carballa et al., 2008). Although sediments and surface water in river system undergo dynamic sorption and desorption and may not have reached chemical equilibrium, an analysis of the distribution of chemicals between sediment and water can still provide useful insight into processes that control the transport and fates of chemicals (Zhu et al., 2008).

The sediment-water partition coefficient $\left(K_{\text {oc }}\right)$ describes the relative affinity or attraction of the estrogens to sediment. Estrogens with higher $K_{\mathrm{oc}}$ values probably have higher concentration in sediment and relatively lower concentration in water. To evaluate a partitioning behavior of estrogens in three rivers, in situ sediment-water partition coefficient $\left(K_{\text {oc }}\right)$ were defined as Eq. (1): 
Table 4

The values of $\log K_{\mathrm{ow}}, \log K_{\mathrm{oc}}^{\prime}$ from literatures and the observed $\log K_{\mathrm{oc}}$ (mean) of six estrogens in three rivers.

\begin{tabular}{|c|c|c|c|c|c|c|}
\hline Estrogens & DES & E1 & E2 & EE2 & E3 & EV \\
\hline $\log K_{\mathrm{ow}}$ & 5.07 & 3.43 & 3.94 & 4.15 & 2.81 & 6.41 \\
\hline $\log K_{\mathrm{oc}}^{\prime}$ & $3.90^{d}$ & $3.00-4.18^{\mathrm{a}}, 3.1^{\mathrm{b}}, 3.16^{\mathrm{c}}$ & $3.13-3.69^{\mathrm{a}}, 3.6^{\mathrm{b}}, 3.30^{\mathrm{c}}$ & $2.90-4.16^{\mathrm{a}}, 3.8^{\mathrm{b}}, 3.31^{\mathrm{c}}$ & $2.5^{\mathrm{b}}, 2.23^{\mathrm{d}}$ & $4.89^{d}$ \\
\hline $\log K_{\mathrm{oc}}$ (Beitang) & 4.28 & 4.02 & 4.22 & 4.25 & 3.64 & 4.57 \\
\hline $\log K_{\text {oc }}(\mathrm{Dagu})$ & 4.48 & 4.12 & 4.27 & 4.21 & 3.88 & 4.47 \\
\hline $\log K_{\text {oc }}$ (Yongding) & 4.83 & 4.60 & 4.57 & 4.80 & 4.39 & 5.05 \\
\hline
\end{tabular}

a Data were obtained from previous reports by Carballa et al. (2008).

b Data were obtained from previous reports by Lai et al. (2000).

c Data were obtained from previous reports by Clara et al. (2004).

d Data were estimated by equation $\left(\log K_{\mathrm{oc}}=0.74 \times \log K_{\mathrm{ow}}+0.15\right)$ (Carballa et al., 2008).

$K_{\mathrm{oc}}=K_{\mathrm{d}} / f_{\mathrm{oc}}, \quad K_{\mathrm{d}}=\left(C_{\mathrm{s}} * 1000 / C_{\mathrm{aq}}\right)$,

where $C_{\mathrm{s}}$ is the solid-phase concentration $\left(\mathrm{ng} \mathrm{kg}^{-1}\right), C_{\mathrm{aq}}$ is the aqueous phase concentration ( $\mathrm{ng} \mathrm{L}^{-1}$ ), $f_{\text {oc }}$ is organic carbon fractions $(\%)$ of the sediment and $K_{\mathrm{d}}$ is the adsorption coefficient $\left(\mathrm{L} \mathrm{kg}^{-1}\right)$. Table 4 show the values of octanol-water partition coefficient $\left(\log K_{\text {ow }}\right)$, sediment-water partition coefficient $\left(\log K_{\mathrm{oc}}^{\prime}\right)$ from literatures and mean in situ sediment-water partition coefficient $\left(\log K_{\text {oc }}\right)$ of estrogens in three rivers. Mean in situ $\log K_{\mathrm{oc}}$ values for each estrogen were calculated with standard deviation range from 0.28 to 0.62 for all sampling sites. Values of the mean in situ $\log K_{\mathrm{oc}}$ for estrogens with low $\log K_{\text {ow }}$ were generally one order of magnitude greater than their corresponding literature values of $\log K_{\mathrm{oc}}^{\prime}$. It indicated that a disequilibrium between the measured sediment and water concentrations occurred. A possible explanation is that the dilution with fresh river water decreases the concentration of estrogens in the water phase and lead to a higher $K_{\mathrm{oc}}$. Furthermore, other reasons can also lead to disequilibrium between the measured sediment and water and create higher $K_{\mathrm{oc}}$. Maruya et al. (1996) reported that the $K_{\mathrm{oc}}$ were higher during the wet period of high surface runoff than during the dry season because atmospheric fallout of combustion particles (i.e., soot) throughout the year and surface runoff during the rainy season could contribute to the PAH content of local sediments. In this study, the $\log K_{\text {oc }}^{\prime}$ from literatures was "experiment" partition coefficient generally obtained from the laboratory. Düring et al. (2002) reported that the experimental $\log K_{\mathrm{oc}}$ of nonylphenol (NP) were lower than "in situ" partition coefficients reported in the literatures. He believed that the "in situ" coefficients are hard to compare with laboratory data. For example, concentrations of sorbate and the ratio between solid and liquid phase were completely different as compared to those in the laboratory experiment. The $K_{\mathrm{oc}}$ obtained in the laboratory was derived by minimizing other processes such as volatilization, degradation, and chemical bonding, summarized as "aging", which should influence significantly the in situ partition coefficients. In addition, organic carbon breakdown during the river sediment diagenesis may cause a similar increase in fugacity and can also create higher $K_{\mathrm{oc}}$ (Gobas and Maclean, 2003). The result was in agreement with studies on other environmental estrogens such as nonylphenol and octylphenol from Tokyo metropolitan area (Isobe et al., 2001) and from Jamaica Bay (Ferguson et al., 2001), pesticides from Guanting reservoir (Xue et al., 2006). The result also indicates that the degree of disequilibrium between sediment and water drops with $\log K_{\mathrm{ow}}$ increasing (Gobas and Maclean, 2003).

The $\log K_{\text {ow }}$ indicates the distribution of a chemical between octanol and water at equilibrium. This coefficient can be used to predict the environmental fate of organic chemicals. The higher the $\log K_{\mathrm{ow}}$, the greater the propensity to be partioned in organic phases. For example, Carballa et al. (2008) used the linear equation about $\log K_{\mathrm{oc}}$ and $\log K_{\mathrm{ow}}$ to model $K_{\mathrm{oc}}$ values of estrogens in the digested sludge and aqueous phase. In this study, the relationships between $\log K_{\text {ow }}$ and mean in situ $\log K_{\text {oc }}$ of estrogens were examined. Their linear correlations were obtained with correlation coef- ficients $\left(R^{2}\right)$ of 0.83 for the Beitang River, 0.82 for the Dagu River and 0.90 for the Yongding New River. Therefore, an estimate to the degree of sediment-water partitioning of estrogens in three rivers can be achieved by the $\log K_{\text {ow }}$ values to evaluate the behavior and fate of estrogens.

\section{Conclusions}

This study showed that higher levels of estrogens from the two drainage rivers could be because of the untreated wastewater discharge. The partitioning of estrogens between water and sediment were found to be influenced by the organic content of the sediment and that the concentration of estrogens in water could be predicted by their in situ $K_{\mathrm{oc}}$, which correlated well with $K_{\mathrm{ow}}$.

\section{Acknowledgements}

This work was supported by Tianjin Science and Technology Program of China (06FZZDSH00900) and "863" National Basic Research Program of China (2007AA06A405).

\section{References}

Adlercreutz, H., Gorbach, S.L., Goldin, B.R., Woods, M.N., Dwyer, J.T., Hämäläinen, E., 1994. Estrogen metabolism and excretion in Oriental and Caucasian women. J. Natl. Cancer I 86, 1076-1082.

Andersen, H., Siegrist, H., Halling-Sørensen, B., Ternes, T.A., 2003. Fate of estrogens in a municipal sewage treatment plant. Environ. Sci. Technol. 37, 4021-4026.

Arcand-Hoy, L.D., Nimrod, A.C., Benson, W.H., 1998. Endocrine-modulating substances in the environment: estrogenic effects of pharmaceutical products. Int. J. Toxicol. 17, 139-158.

Baronti, C., Curini, R., D’Ascenzo, G., Di Corcia, A., Gentili, A., Samperi, R., 2000 Monitoring natural and synthetic estrogens at activated sludge sewage treatment plants and in a receiving river water. Environ. Sci. Technol. 34, 5059-5066.

Belfroid, A.C., Van der Horst, A., Vethaak, A.D., Schäfer, A.J., Rijs, G.B., Wegener, J., Cofino, W.P., 1999. Analysis and occurrence of estrogenic hormones and their glucuronides in surface water and waste water in The Netherlands. Sci. Total Environ. 225, 101-108.

Björkblom, C., Salste, L., Katsiadaki, I., Wiklund, T., Kronberg, L., 2008. Detection of estrogenic activity in municipal wastewater effluent using primary cell cultures from three-spined stickleback and chemical analysis. Chemosphere 73, 10641070.

Braga, O., Smythe, G.A., Schäfer, A.I., Feitz, A.J., 2005. Steroid estrogens in ocean sediments. Chemosphere 61, 827-833.

Campbell, C.G., Borglin, S.E., Green, F.B., Grayson, A., Wozei, E., Stringfellow, W.T., 2006. Biologically directed environmental monitoring, fate, and transport of estrogenic endocrine disrupting compounds in water: a review. Chemosphere 65, 1265-1280.

Carballa, M., Fink, G., Omil, F., Lema, J.M., Ternes, T., 2008. Determination of the solid-water distribution coefficient $\left(K_{\mathrm{d}}\right)$ for pharmaceuticals, estrogens and musk fragrances in digested sludge. Water Res. 42, 287-295.

Cargouët, M., Perdiz, D., Mouatassim-Souali, A., Tamisier-Karolak, S., Levi, Y., 2004 Assessment of river contamination by estrogenic compounds in Paris area (France). Sci. Total Environ. 324, 55-66.

Casey, F.X.M., Larsen, G.L., Hakk, H., Šimůnek, J., 2003. Fate and transport of $17 \beta-$ estradiol in soil-water systems. Environ. Sci. Technol. 37, 2400-2409.

Chen, C.Y., Wen, T.Y., Wang, G.S., Cheng, H.W., Lin, Y.H., Lien, G.W., 2007. Determining estrogenic steroids in Taipei waters and removal in drinking water treatment using high-flow solid-phase extraction and liquid chromatography/tandem mass spectrometry. Sci. Total Environ. 378, 352-365. 
Clara, M., Strenn, B., Saracevic, E., Kreuzinger, N., 2004. Adsorption of bisphenol-A, $17 \beta$-estradiole and $17 \alpha$-ethinylestradiole to sewage sludge. Chemosphere 56 , 843-851.

Düring, R.A., Krahe, S., Gäth, S., 2002. Sorption behavior of nonylphenol in terrestrial soils. Environ. Sci. Technol. 36, 4052-4057.

Esperanza, M., Suidan, M.T., Marfil-Vega, R., Gonzalez, C., Sorial, G.A., McCauley, P., Brenner, R., 2007. Fate of sex hormones in two pilot-scale municipal wastewater treatment plants: conventional treatment. Chemosphere 66, 1535-1544.

Ferguson, P.L., Iden, C.R., Brownanwell, B.J., 2001. Distribution and fate of neutral alkylphenol ethoxylate metabolites in a sewage-impacted urban estuary. Environ. Sci. Technol. 35, 2428-2435.

Gobas, F.A.P.C., Maclean, L.G., 2003. Sediment-water distribution of organic contaminants in aquatic ecosystems: the role of organic carbon mineralization. Environ. Sci. Technol. 37, 735-741.

Gomes, R.L., Acioglu, E., Scimshaw, M.D., Lester, J.N., 2004. Steroid estrogen determination in sediment and sewage sludge: a critique of sample preparation and chromatographic/mass spectrometry considerations, incorporating a case study in method development. Trends Anal. Chem. 23, 737-744.

Hanselman, T.A., Graetz, D.A., Wilkie, A.C., 2003. Manure-borne estrogens as potential environmental contaminants: a review. Environ. Sci. Technol. 37, 5471-5478.

Hintemann, T., Schneider, C., Schöler, H.F., Schneider, R.J., 2006. Field study using two immunoassays for the determination of estradiol and ethinylestradiol in the aquatic environment. Water Res. 40, 2287-2294.

Holthaus, K.I.E., Johnson, A.C., Jürgens, M.D., Williams, R.J., Smith, J.J.L., Carter, J.E., 2002. The potential for estradiol and ethinylestradiol to sorb to suspended and bed sediments in some English rivers. Environ. Toxicol. Chem. 21, 25262535.

Isobe, T., Nishiyama, H., Takada, A., Nakashima, H., 2001. Distribution and behavior of nonylphenol, octylphenol, and nonylphenol monoethoxylate in Tokyo metropolitan area: their association with aquatic particles and sedimentary distributions. Environ. Sci. Technol. 35, 1041-1049.

Isobe, T., Shiraishi, H., Yasuda, M., Shinoda, A., Suzuki, H., Morita, M., 2003. Determination of estrogens and their conjugates in water using solid-phase estraction followed by liquid chromatography-tandem mass spectrometry. J. Chromatogr. A 984, 195-202.

Isobe, T., Serizawa, S., Horiguchi, T., Shibata, Y., Managaki, S., Takada, H., Morita, M., Shiraishi, H., 2006. Horizontal distribution of steroid estrogens in surface sediments in Tokyo Bay. Environ. Pollut. 144, 632-638.

Jeannot, R., Sabik, H., Sauvard, E., Dagnac, T., Dohrendorf, K., 2002. Determination of endocrine-disrupting compounds in environmental samples using gas and liquid chromatography with mass spectrometry. J. Chromatogr. A 974, 143159

Johnson, K., 1999. The partitioning of natural and synthetic oestrogens between aqueous and solid phases, M.Sc. Dissertation, Imperial College London, London, UK, p. 102.

Kawaguchi, M., Ishii, Y., Sakui, N., Okanouchi, N., Ito, R., Inoue, K., Saito, K., Nakazwa, H., 2004. Stir bar sorptive estraction with in situ derivatization and thermal desorption-gas chromatography-mass spectrometry in the multi-shot mode for determination of estrogens in river water samples. J. Chromatogr. A $1049,1-8$

Kolodziej, E.P., Harter, T., Sedlak, D.L., 2004. Dairy wastewater, aquaculture, and spawning fish as sources of steroid hormones in the aquatic environment. Environ. Sci. Technol. 38, 6377-6384.

Kolpin, D.W., Furlong, ET., Meyer, M.T., Thurman, E.M., Zaugg, S.D., Barber, L.B. Buxton, H.T., 2002. Pharmaceuticals, hormones, and other organic wastewater contaminants in US streams, 1999-2000: a national reconnaissance. Environ. Sci. Technol. 36, 1202-1211

Kuch, K.M., Ballschmiter, K., 2001. Determination of endocrine-disrupting phenolic compounds and estrogens in surface and drinking water by HRGC-(NCI)-MS in the picogram per liter range. Environ. Sci. Technol. 35, 3201-3206.

Kuster, M., López de Alda, M.J., Barceló, D., 2004. Analysis and distribution of estrogens and progestogens in sewage sludge, soils and sediments. Trends Anal. Chem. 23, 790-798.

Labadie, P., Budzinski, H., 2005. Determination of steroidal hormone profiles along the Jalle d'Eysines River (near Bordeaux, France). Environ. Sci. Technol. 39, 5113-5120.

Labadie, P., Budzinski, H., 2006. Alteration of steroid hormone profile in juvenile turbot (Psetta maxima) as a consequence of short-term exposure to $17 \alpha$ ethynylestradiol. Chemosphere 64, 1274-1286.

Lai, K.M., Johnson, K.L., Scrimshaw, M.D., Lester, J.N., 2000. Binding of waterborne steroid estrogens to solid phases in river and estuarine systems. Environ. Sci. Technol. 34, 3890-3894.

Legler, J., Dennekamp, M., Vethaak, A.D., Brouwer, A., 2002. Detection of estrogenic activity in sediment-associated compounds using in vitro reporter gene assays. Sci. Total Environ. 293, 69-83.

Liu, H.X., Zhang, Q.H., Wang, Y.W., Cai, Z.W., Jiang, G.B., 2007. Occurrence of polychlorinated dibenzo-p-dioxins, dibenzofurans and biphenyls pollution in sediments from the Haihe River and Dagu Drainage River in Tianjin City, China. Chemosphere 68, 1772-1778.

Liu, R., Zhou, J.L., Wilding, A., 2004. Microwave-assisted extraction followed by gas chromatography-mass spectrometry for the determination of endocrine disrupting chemicals in river sediments. J. Chromatogr. A 1038, 143-159.
Lopez de Alda, M.J., Gil, A., Paz, E., Barcelo, D., 2002. Occurrence and analysis of estrogens and progestogens in river sediments by liquid chromatographyelectrospray-mass spectrometry. Analyst 127, 1299-1304.

Maruya, K.A., Risebrough, R.W., Horne, A.J., 1996. Partitioning of polynuclear aromatic hydrocarbons between sediments from San Francisco Bay and their porewaters. Environ. Sci. Technol. 30, 2942-2947.

Noppe, H., Verslycke, T., De Wulf, E., Verheyden, K., Monteyne, E., Van Caeter, P., Janssen, C.R., De Brabander, H.F., 2007. Occurrence of estrogens in the Scheldt estuary: a 2-year survey. Ecotox. Environ. Safe. 66, 1-8.

Sabljic, A., Gusten, H., Verhaar, H., Hermens, J., 1995. QSAR modelling of soil sorption. Improvements and systematics of $\log K_{\mathrm{oc}}$ vs. $\log K_{\mathrm{ow}}$ correlations. Chemosphere 31, 4489-4514.

Samir, K.K., Xian, B., Thompson, M.L., Sung, S., Ong, S.-K., Leeuwen, J.V., 2006. Fate transport, and biodegradation of natural estrogens in the environment and engineered systems. Environ. Sci. Technol. 40, 6537-6545.

Shen, J.H., Gutendorf, B., Vahl, H.H., Shen, L., Westendorf, J., 2001. Toxicological profile of pollutants in surface water from an area in Taihu Lake, Yangtze Delta. Toxicology 166, 71-78.

Song, M.Y., Xu, Y., Jiang, Q.T., Lam, P.K.S., O’Toole, D.K., Giesy, J.P., Jiang, G.B., 2006 Measurement of estrogenic activity in sediments from Haihe and Dagu River, China. Environ. Int. 32, 676-681.

Tabata, A., Kashiwa, S., Ohnishi, Y., Ishikawa, H., Miyamoto, N., Itoh, M., Magara, Y. 2001. Estrogenic influence of estradiol-17 $\beta, p$-nonylphenol and bisphenol $A$ on Japanese Medaka (Oryzias iatipes) at detected environmental concentrations. Water Sci. Technol. 43, 109-116.

Ternes, T.A., Stumpf, M., Mueller, J., Haberer, K., Wilken, R.D., Servos, M., 1999a Behavior and occurrence of estrogens in municipal sewage treatment plantsI. Investigations in Germany, Canada and Brazil. Sci. Total Environ. 225, $81-$ 90

Ternes, T.A., Kreckel, P., Mueller, J., 1999b. Behaviour and occurrence of estrogens in municipal sewage treatment plants-II. Aerobic batch experiments with activated sludge. Sci. Total Environ. 225, 91-99.

Ternes, T.A., Andersen, H., Gilberg, D., Bonerz, M., 2002. Determination of estrogen in sludge and sediments by liquid extraction and GC/MS/MS. Anal. Chem. 74 3498-3504.

Tianjin Environmental Protection Bureau, 2001. Environmental Quality Report of Tianjin in 1996-2000.

Tianjin Municipality Government, 2005. Yearbook of Tianjin. Tianjin: Tianjin Yearbook Press.

Trenholm, R.A., Vanderford, B.J., Holady, J.C., Rexing, D.J., Snyder, S.A., 2006. Broad range analysis of endocrine disruptors and pharmaceuticals using gas chromatography and liquid chromatography tandem mass spectrometry. Chemosphere 65, 1990-1998.

Vethaak, A.D., Lahr, J., Schrap, S.M., Belfroid, A.C., Rijs, G.B.J., Gerritsen, A., De Boer, J. Bulder, A.S., Grinwis, G.C.M., Kuiper, R.V., Legler, J., Murk, T.A.J., Peijnenburg, W., Verhaar, H.J.M., De Voogt, P., 2005. An integrated assessment of estrogenic contamination and biological effects in the aquatic environment of The Netherlands. Chemosphere 59, 511-524.

Viganò, L., Benfenati, E., van Cauwenberge, A., Eidem, J.K., Erratico, C., Goksøyr, A. Kloas, W., Maggioni, S., Mandich, A., Urbatzka, R., 2008. Estrogenicity profile and estrogenic compounds determined in river sediments by chemical analysis, ELISA and yeast assays. Chemosphere 73, 1078-1089.

Williams, R.J., Johnson, A.C., Smith, J.J.L., Kanda, R., 2003. Steroid estrogens profiles along river stretches arising from sewage treatment works discharges. Environ. Sci. Technol. 37, 1744-1750.

Xue, N.D., Zhang, D.R., Xu, X.B., 2006. Organochlorinated pesticide multiresidues in surface sediments from Beijing Guanting reservoir. Water Res, 40, 183-194.

Yamamoto, H., Liljestrand, H.M., Shimizu, Y., Morita, M., 2003. Characteristics on the sorption of selected endocrine disruptors by dissolved organic matter surrogates. Environ. Sci. Technol. 37, 2646-2657.

Yang, L.H., Luan, T.G., Lan, C.Y., 2006. Solid-phase microextraction with on-fiber silylation for simultaneous determinations of endocrine disrupting chemicals and steroid hormones by gas chromatography-mass spectrometry. J. Chromatogr. A 1104, 23-32.

Ying, G.G., Kookana, R.S., Ru, Y.J., 2002. Occurrence and fate of hormone steroids in the environment. Environ. Int. 28, 545-551.

Zha, J.M., Sun, L.W., Ma, M., Wang, Z.J., 2008. Assessment of $17 \alpha$-ethinylestradiol effects and underlying mechanisms in a continuous, multigeneration exposure of the Chinese rare minnow (Gobiocypris, rarus). Toxicol. Appl. Pharmacol. 226, 298-308.

Zhang, Y.P., Zhou, J.L., 2008. Occurrence and removal of endocrine disrupting chemicals in wastewater. Chemosphere $73,848-853$.

Zhou, Y.Q., Wang, Z.J., Jia, N., 2007. Formation of multiple trimethylsilyl derivatives in the derivatization of $17 \alpha$-ethinylestradiol with BSTFA or MSTFA followed by gas chromatography-mass spectrometry determination. J. Environ. Sci. 19, 879-884.

Zhou, Y.Q., Zhou, J., Xu, Y.P., Zha, J.M., Ma, M., Wang, Z.J., 2009. An alternative method for the determination of estrogens in surface water and wastewater treatment plant effluent using pre-column trimethylsilyl derivatization and gas chromatography/mass spectrometry. Environ. Monit. Assess. Online first.

Zhu, L.Z., Chen, Y.Y., Zhou, R.B., 2008. Distribution of polycyclic aromatic hydrocarbons in water, sediment and soil in drinking water resource of Zhejiang Province, China. J. Hazard. Mater. 150, 308-316. 